\title{
DISCURSIVE MECHANISMS OF NEWS MEDIA - INVESTIGATING ATTRIBUTION AND ATTITUDINAL POSITIONING
}

\author{
FLAVIA CAVALIERE \\ University of Naples Federico II \\ 1 Via Porta di Massa, Naples, 80133, Italy
}

\begin{abstract}
The case of 17-year-old Afro-American Trayvon Martin shot dead in 2012 by white neighborhood watch George Zimmerman is generally reported as the first killing of what over the last few years seemed an epidemic of lethal violence committed on mostly unarmed afro-American civilians which ignited other waves of protests and rioting across the whole country. Immediately after Martin's fatal shooting the initial absence of charges against Mr. Zimmerman's conduct, owing to a controversial selfdefense law, prompted nationwide protest and unrest. An online petition calling for a prosecution of Zimmerman garnered over two million signatures; a process against Zimmerman was then started, though in 2013 his acquittal gave birth to the international activist movement \#BlackLivesMatter on social media. All these events have since then resonated in the sensationalized reports of the media which «employ textual strategies which foreground the speech act of offering values and beliefs» (Fowler 2013: 209).

Within Martin \& White's Appraisal Framework (2008) qualitative samples from the US print media coverage (The New York Times and Orlando Sentinel) of Trayvon Martin's story are investigated. More specifically, our focus is mainly on attribution and evidentiality, i.e. on the interplay of directly-quoted or indirectly-reported speech that journalistic writers use to attribute viewpoints and versions of events to a variety of external sources, especially potentially controversial meanings largely confined to material attributed to quoted sources. We aim at providing a socio-critical interpretation of how the supposedly unbiased media narratives of ethnic affairs contributed to inflame racial passions, and, by funneling audience attention toward certain topics, influenced public perceptions of important issues.
\end{abstract}

Keywords: media coverage, racial issues, attribution, attitudinal positioning, public perception

\section{INTRODUCTION KEY PEOPLE AND FACTS}

The case of 17-year-old unarmed Afro-American Trayvon Martin, shot dead in February 2012 by white neighbourhood watch George Zimmerman, stands as the first mediatic symbol of the many racially-profiled confrontations the US has been coping with ever since. Amidst the growing media frenzy and active participation of the public, a whirlwind of controversy and political debate surrounded the reports of this murder. The shooting, initially covered by the Florida media alone, was soon seized on by the national media, and race was reported as central to the tragedy since Zimmerman, a white male of Latino heritage born from a Peruvian mother, was accused of racially profiling the Afro-American teen Martin.

The Zimmerman affair highlighted in fact race relations in the United States, prompting nationwide protest and unrest, and his trial became one of the most raciallycharged, and apparently most politically motivated prosecutions in recent U.S. history (Adjei, Gill 2013, Bhandaru 2013). 
On a rainy night on Feb. $26^{\text {th }}, 2012$, the $17-$ year-old Trayvon Martin, was heading back to the house of his father's fiancée at the Retreat at Twin Lakes, a gated community in Sanford in central Florida ${ }^{1}$. Martin had gone to a 7-Eleven store, a convenience store, to buy candies and iced-tea for his step-brother, and was wearing a hooded sweat shirt - something his parents and their supporters maintain led Zimmerman to racially profile the unarmed teenager, and which, for this reason, would become a symbol' ${ }^{2}$.

While walking through the complex, Trayvon was spotted by George Zimmerman, a selfappointed neighbourhood watch volunteer, who was patrolling the area in his vehicle. Zimmerman called authorities to report someone suspicious, since, in his recorded words, "he seems like up to no good, on drugs or something [...] and black"”.

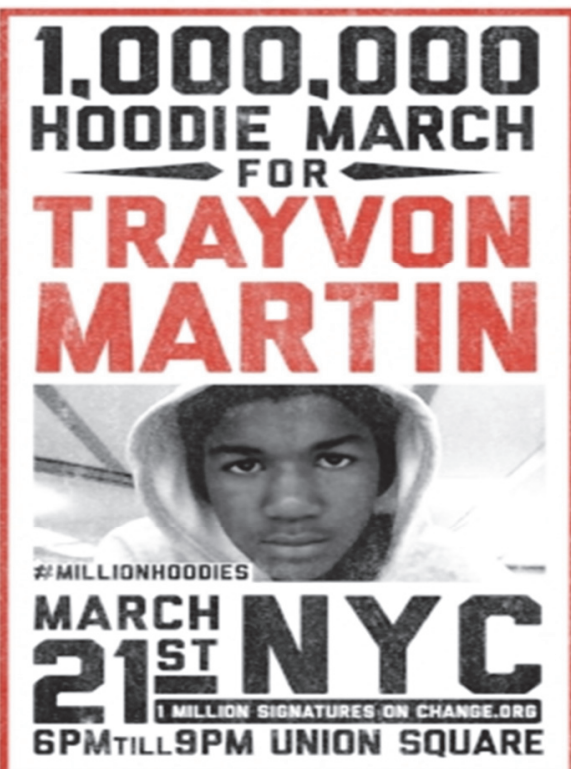

The dispatcher advised him to let the police handle it, but Zimmerman ignored that and proceeded to follow Martin. A confrontation ensued and Martin was shot in the chest. Zimmerman admitted from the beginning that he had fired a single shot from his handgun, killing Martin. Nevertheless, five hours after Trayvon's murder, Zimmerman was released on his claim of having acted in self-defense, and his right to defend himself even with lethal force, under Florida's controversial 'Stand Your Ground' statute.

However, a petition on Change.org, created by Trayvon Martin's parents, calling for a full investigation and prosecution of Zimmerman, surpassed two million signatures, while, as a sign of solidarity, hundreds of Trayvon's supporters organized nationwide rallies and marches wearing hoodies, same as the one Trayvon was wearing the night he was murdered and then walked in the so-called 'Million Hoodie March' in New York, a march which launched the 'Million Hoodies Movement".

After weeks of protests and demonstrations across the nation, the furor reached all the way to the White House. On March 23 ${ }^{\text {rd }}$, 2012 President Barack Obama himself

${ }^{1}$ George Zimmerman acquitted in Trayvon Martin case. R. Luscombe. 14 July 2014. https://www.theguardian.com/world/2013/jul/14/zimmerman-acquitted-killing-trayvon-martin.

${ }^{2}$ Hoodies would later play a frequent role at protests, offered as symbols of racial profiling. See footnote 4 .

3 Trayvon Martin shooting, minute by minute. https://www.youtube.com/watch?v=ia0w_dOj7R4.

${ }^{4}$ As explained by its own founders, the Hoodies Movement for Justice, was formed on March 19, 2012 in response to the media's failure to adequately report on the events leading to Trayvon's death. The Million Hoodies national network that exist today officially launched in 2014, designed to develop a new generation of human rights leaders on the front lines for transformative social change, in partnership with Change.org, Million Hoodies, successfully stopped Oklahoma from passing a discriminatory law that would criminalize Black youth wearing hoodies in public spaces». https://www.millionhoodies.net/about/. 
spoke out publicly for the first time on the ever-growing controversy over the shooting of Trayvon Martin, saying that the incident called for national "soul-searching", and he also added

Martin's parents are right to expect that all of us as Americans are going to take this with the seriousness it deserves, and we are going to get to the bottom of exactly what happened. If I had a son he would look like Trayvon ${ }^{5}$.

As the controversy roared, a special state prosecutor was finally appointed to review the case.

Zimmerman was eventually arrested and charged with second-degree murder and manslaughter, though on July 13, 2013 he was acquitted by a Florida jury.

This outcome was frequently reported as representative of the general state of race relations in the U.S. The ensuing national debate led to a confrontation that touched off issues of race and guns, bringing to the fore a multifaceted and contested vision of the facts. The role and impact of multi-media and cross-media communication in the shaping of the events cannot be overestimated, as voiced by many journalistic authors, for example:

When the criminal justice system appears to fall short, the court of public opinion takes over and suddenly both victim and ostensible perpetrator go on trial. But what is also being adjudicated is our ability to debate highly charged issues in a very divided media landscape. Let's be careful out there (Carr 2012) .

His acquittal gave birth to the international activist movement 'Black Lives Matter' (BLM) with the hashtag \#BlackLivesMatter on social media.

This movement, which would change the country is considered Trayvon Martin's legacy. But how did «one black child's death on a dark, rainy street in a small Florida town become the match that lit a civil rights crusade?»7. Since Trayvon was murdered, his mother Sybrina Fulton has been on the national stage, and has devoted her life to travelling around the country to speak about racial violence on behalf of the 'Trayvon Martin Foundation' established in March 2012 as a social justice not-for-profit organization committed to ending senseless gun violence ${ }^{8}$.

Trayvon Martin's death is generally reported as the first killing of what, over the last few years, has seemed an epidemic of lethal violence committed on mostly unarmed

5 J. Calmes, H. Cooper. A Personal Note as Obama Speaks on Death of Boy, The New York Times, March $23^{\text {rd }}$, 2012. http://www.nytimes.com/2012/03/24/us/politics/obama-talks-of-tragedy-not-racein-florida-killing.html.

${ }^{6}$ D. Carr. The Media Equation. A Shooting, and Instant Polarization. The New York Times. April 1, 2012.

${ }^{7} \mathrm{https} / /$ www.penguinrandomhouse.com/books/243453/rest-in-power-by-sybrina-fulton-andtracy-martin/\#.

${ }^{8}$ The Foundation provides scholarships, mentoring, financial literacy and parenting assistance particularly to the "Circle of Mothers" and "Circle of Fathers", which gather women and men who have lost children to gun violence and organizes many significant events which include, for instance, 'The Trayvon Martin Remembrance Dinner' and the 'Annual Peace Walk and Peace Talk'. https://trayvonmartinfoundation.org/. 
afro-American civilians at the hands of police, as well as several deaths while in police custody (Michael Brown in Ferguson, Eric Garner in Staten Island, Laquan McDonald in Chicago, Tamir Rice in Cleveland, Walter Scott in North Carolina, Freddie Gray in Baltimore, Alfred Okwera Olango in suburban San Diego, to name but a few), which ignited other waves of protests and rioting across the whole country. The echo of Trayvon Martin's shooting still resonates, five years after his death as a symbol of social justice activism. On February $26^{\text {th }} 2017$, on Oscar night, for instance, some Hollywood celebrities and public figures shared on their social media photos of themselves while wearing hoodies, or a sweatshirt emblazoned with Trayvon' name, sending worldwide the message "Our hoodies are still up and the movement is still strong". In May 2017, Florida Memorial University announced Trayvon Martin as Recipient of a Posthumous Bachelor of Science Degree in Aviation, as an iconic figure of the fight for equal justice for all ${ }^{10}$.

Trayvon Martin's case has clearly had an unsettling impact on US societal values and belief systems, increased distrust between the police and black community and prompted an inflamed national discussion about race and self-defense which, as said above, resonated in the sensationalized reports of the media. It is well-known that "the media convey public knowledge, as well as expressed or implicit opinions, about social groups and events and [...] provide an ideological framework for the interpretation of ethnic events. This framework may also act as a legitimation for prejudices and discrimination" (van Dijk 2015:209). News media, in particular, can easily favour particular value positions (affectual and judgmental), while employing a relatively impersonal style in which evaluations and other potentially contentious meanings are largely confined to material attributed to quoted sources (White 2005, 2012).

Accordingly, by exploring the (print) media coverage of this story, where legal and sociological debates are involved (Babacan et al. 2009), the present study - within a broad critical discourse analytical perspective — aims at providing a socio-critical interpretation of how the media discourse/s contributed to ignite racial passions, and to generate new and potentially disruptive social dynamics.

At the same time, this study attempts to highlight how the escalation of raciallyprofiled violence, and other outrages which have taken place in US society since Trayvon's shooting, suggest that its legislation is possibly no longer able to cope with a nation where, by 2020 , the word 'minorities' will lose its present significance.

In this scenario, qualitative samples from the US press media (The New York Times and Orlando Sentinel) are analyzed, and the legal and socio-cultural implications discussed.

9 See 'Hoodies up': Celebrities honor Trayvon Martin five years after his death. Maeve McDermott, USATODAY.26 February 2017. https://www.usatoday.com/story/life/entertainthis/2017/02/26/ celebrities-honor-trayvon-martin-five-years-after-his-death/98452544/.

${ }^{10}$ Florida University to Award Posthumous Degree to Trayvon Martin. Christine Hauser 5 May, 2017. https://www.nytimes.com/2017/05/05/us/trayvon-martin-degree.html. 


\section{BACKGROUND: IDEOLOGIES AND LAWS FLORIDA'S CONTROVERSIAL 'STAND YOUR GROUND’ STATUTE}

Grounded in the USA Gun Culture/s - a culture of no immediate understanding for Europe — the 776.013 Statute on "Home protection; use or threatened use of deadly force; presumption of fear of death or great bodily harm" "11 was first adopted in Florida in 2005 and then enacted in some form in more than 20 states. Commonly known as the 'Stand Your Ground' law (or 'shoot first law', as its critics say), the 776.013 Statute was drafted and promoted by the National Rifle Association, and explicitly allows the use of deadly force, and it never requires

that one withdraw or retreat before using deadly force, and the requirements of reasonableness are attenuated or essentially removed because the other witness is dead, and the defender may shade the truth, [and so determine in point of fact a prosecutorial immunity]. Thus, Stand Your Ground laws may provide a rock-solid defense to paranoid or dangerously aggressive people who are armed with deadly force. (O' Meara 2012) ${ }^{12}$.

Apparently, the Trayvon Martin shooting suggests that lawmakers and gun advocates have gone too far in authorizing the use of deadly force; Zimmerman's acquittal was due to the 776.013 and 776.032 Statutes $^{13}$. From the contentious debate on such no duty to retreat laws and related events a basic question arises for the (thoughtful) United States citizens: what does a doctrine that relieves U.S. citizens, in their homes, of the duty to try to flee an intruder's attack before resorting to force in self defense, have to do with shoot-outs in public streets? Attorney-General Eric Holder's emphasized how the "stand-your-ground' laws senselessly expand the concept of self-defence and sow dangerous conflict in our neighbourhoods", thus denouncing the masked dangers in its formulation.

\section{METHODOLOGY AND AIMS}

Within a broadly conceived discourse analysis approach, our investigation of qualitative samples from the US print media coverage (The New York Times and Orlando Sentinel) of Trayvon Martin's story is an application of the Appraisal Framework (Martin \& White 2005; White 2012 a, b). The Appraisal Framework (AF) appears particularly useful for our analysis, since it mainly deals with Media Commentary and Journalistic voice $^{14}$, and is suitable «to explore 'objectivity' and 'subjectivity' in journalistic discourse

${ }^{11} \mathrm{http} / / /$ www.leg.state.fl.us/statutes/index.cfm?App_mode=Display_Statute\&URL=07000799/0776/Sections/0776.013.html.

12 As G. O' Meara, a former prosecutor, an associate professor of law at Marquette University, stated in his article "Stand Your Ground Laws Are Unnecessary". The New York Times. March 21, 2012 .

${ }^{13}$ Statute 776.032 on 'Immunity from criminal prosecution and civil action for justifiable use of force' reads as follows: "A person who uses force as permitted in s. 776.012, s. 776.013, or s. 776.031 is justified in using such force and is immune from criminal prosecution and civil action for the use of such force".

${ }^{14}$ P.R.R. White, Evaluative semantics and ideological positioning in journalistic discourse - a new framework for analysis, in I. Lassen (ed.), Mediating Ideology in Text and Image: ten critical studies, John Benjamins, Amsterdam, 2006, pp. 45-73. 
and to explore how the different 'voices' or sub-registers of journalistic discourse can be seen to vary according to their different use of Appraisal values $\gg{ }^{15}$.

More specifically, a major focus is on attribution and evidentiality, i.e. on the interplay of directly-quoted or indirectly-reported speech that journalistic writers use to attribute viewpoints and versions of events to a variety of external sources, especially potentially controversial meanings are largely confined to material attributed to quoted sources. Viewed from the Appraisal Framework perspective, attribution and so-called 'evidentiality' are concerned with the linguistic resources by which speakers/writers include, and adopt a stance towards what they represent as the words, observations, beliefs and viewpoints of other speakers/writers. This is an area which has been widely covered in the literature under such headings as [...] "direct and indirect speech", "intertextuality" and, following Bakhtin, "heteroglossia".

At its most basic level, this attribution or intertextual positioning is brought into play when a writer/speaker chooses to quote or reference the words or thoughts of another.

Furthermore, integrative resources for our analysis were found in Martin and White's The Language of Evaluation: appraisal in English ${ }^{16}$, where the resources of appraisal are related to the categories of 'news', 'analysis' and 'comment/opinion'. Accordingly, three media roles are identified, in line with the evaluative choices entailed in the roles of reporter, correspondent and commentator, as follows:

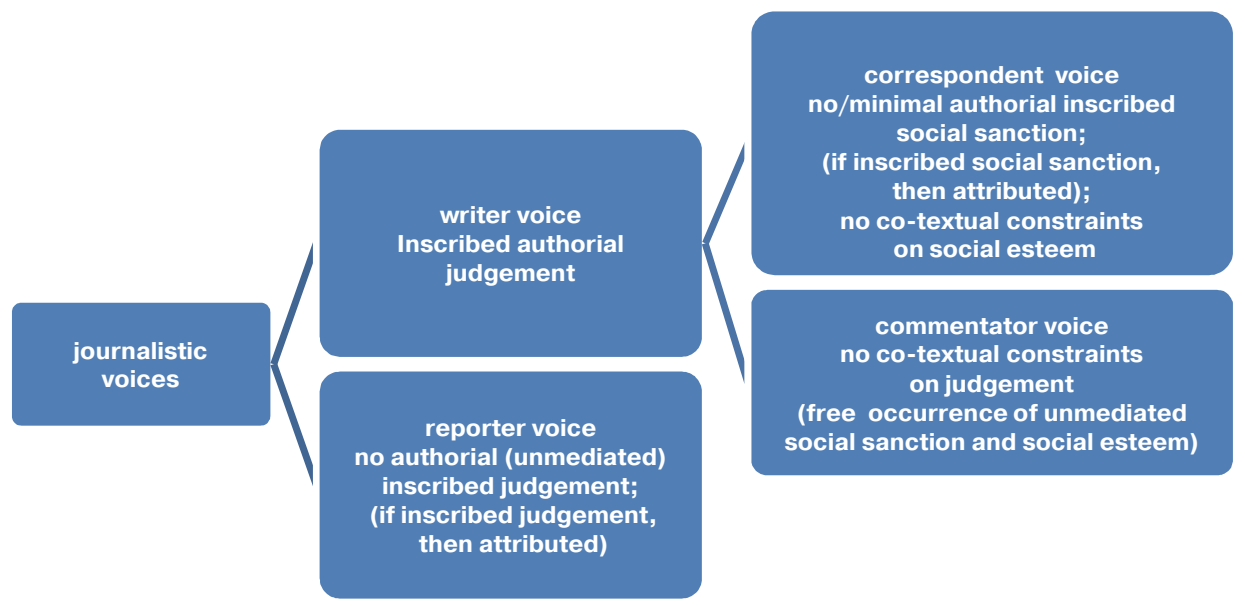

Figure 1. (Martin and White 2005: 173)

Of relevance for our analysis is that the commentator voice has "no co-textual constraints on judgement" with "free occurrence of unmediated social sanction and social esteem" (Martin and White 2005: 173). Indeed, in the excerpts under investigation, among the less autonomous reporters' voices, the commentators' voices are more noticeable and authoritative.

${ }_{15}$ R. Iedema, S. Feez, P.R.R. White, Media Literacy, Sydney, Disadvantaged Schools Program, NSW Department of School Education, 1994.

${ }^{16}$ J.R. Martin, P.R.R. White. The Language of Evaluation. Palgrave Macmillan, London \& New York, 2005. 


\section{ATTRIBUTION}

Our analysis also drew on P.R. White's more recent investigations in the axiological/value positions of 'reporter's voice' in news stories through attribution and attitudinal positioning (2012b) ${ }^{17}$. Attribution within Appraisal Framework (AF) theory, is defined as a mechanism whereby the journalistic author, through directly-quoted or indirectly-reported speech, presents the viewpoints and versions of event on offer in an article as derived from some external source (White 2012: 57).

In White's account ${ }^{18} \mathrm{AF}$ developed as researchers felt the need to define more precisely the attitudinal values by which texts apply social norms to evaluate human behaviour. Appraisal is now an umbrella term to cover all evaluative uses of language, whose two core concerns are: how speakers/writers adopt and indicate positive or negative attitudes and how they negotiate these attitudinal and other types of positioning with actual or potential dialogic partners ${ }^{19}$.

The AF thus explores the way language is used to evaluate and/or to adopt stances, to construe textual personas. AF investigates how affective involvement can be conveyed through a set of indicators including exclamation, repetition, intensification and attitudinal lexis, and so on.

This could clarify certain patterns by which so-called 'objective' texts within the media favour certain values of attitude while excluding others ${ }^{20}$. AF consequently deals with Media Commentary and Journalistic voice ${ }^{21}$, where it appears particularly useful «to explore 'objectivity' and 'subjectivity' in journalistic discourse and to explore how the different 'voices' or sub-registers of journalistic discourse can be seen to vary according to their different use of Appraisal values ${ }^{22}$.

17 P.R.R. White 2012. Exploring the axiological workings of 'reporter voice' news stories Attribution and attitudinal positioning. Discourse, Context and Media. Volume 1, Issues 2-3, JuneSeptember, 57-67.

${ }_{18}$ P.R.R. White. Telling Media Tales: the News Story As Rhetoric, Unpublished PhD, University of Sydney, Sydney, 1998. http://www. grammatics.com/appraisal/Appraisal KeyReferences.html, (18 June 2012).

19 This concept of 'dialogism' clearly refers to the works of Bakhtin/Voloshinov. In the Bakhtinian sense discourse and dialogistic exchanges necessarily has a dialogic dimension. We never speak in a vacuum: whatever is said always exists in response to things that have been said before and in anticipation of things that will be said in response. Every utterance is refracted through a host of other antagonistic idioms. Linguistic exchanges are dynamic, relational and engaged in a process of endless re-definition of the world, though certain uses of language maximize the dialogic nature of words, while others attempt to restrict their poly-vocality. Cf. V.N. Voloshinov, Marixism and the Philosophy of Language, Bakhtinian Thought - an Introductory Reader, S. Dentith, L. Matejka \& I.R. Titunik, (trans), London, Routledge, 1995.

${ }^{20}$ J.R. Martin, English text. System and structure, Philadelphia, John Benjamins Publishing Company, 1992, pp. 523, 535.

${ }^{21}$ P.R.R. White, Evaluative semantics and ideological positioning in journalistic discourse - a new framework for analysis, in I. Lassen (ed.), Mediating Ideology in Text and Image: ten critical studies, John Benjamins, Amsterdam, 2006, pp. 45-73.

${ }_{22}$ R. Iedema, S. Feez, P.R.R.White, Media Literacy, Sydney, Disadvantaged Schools Program, NSW Department of School Education, 1994. 
The system of Appraisal comprises three large interactive subsystems Attitude

Gradation

Engagement

\section{Attitude}

Attitude concerns the speakers' positive/ negative assessment of people, places, things, state of affairs and their associate emotional/affectual responses. Attitude can be conveyed in various ways, it may be expressed not by single words (though individual words can be attitudinal) but by phrases and sentences, and, above all, by the interaction of diverse elements of statements which transmit the writers' propositions and viewpoints, and, therefore, need to be analysed as a whole.

Attitudinal Positioning may concern positive and negative evaluations involving

I. Affect

II. Judgement

III. Appreciation

Martin and White have schematized these three subcategories as in Table 1:

Table 1

Clause frames for distinguishing types of Attitude

\begin{tabular}{|l|l|l|}
\hline \multicolumn{1}{|c|}{ System } & \multicolumn{1}{|c|}{ Clause frame } & \multicolumn{1}{c|}{ Example } \\
\hline Affect & $\begin{array}{l}\text { person feels affect about something } \\
\text { it makes person feel affect that [proposition] }\end{array}$ & $\begin{array}{l}\text { I feel happy (about that/that they've come). } \\
\text { It makes me feel happy that they've come }\end{array}$ \\
\hline Judgement & $\begin{array}{l}\text { it was Judgement for/of person to do that } \\
\text { (for person) to do that was Judgement }\end{array}$ & $\begin{array}{l}\text { It was silly of/for them to do } \\
\text { For them) to do that was silly. }\end{array}$ \\
\hline Appreciation & $\begin{array}{l}\text { Person considers something appreciation } \\
\text { Person sees something as appreciation }\end{array}$ & $\begin{array}{l}\text { I consider it beautiful. } \\
\text { They see it as beautiful }\end{array}$ \\
\hline
\end{tabular}

Source: J.R. Martin, P.R.R. White, The Language of Evaluation: The Appraisal Framework, London \&New York, Palgrave Macmillan, 2005, pp. 58-9.

Affect is thus concerned with emotional reactions and disposition;

Judgement refers to meanings which serve to evaluate human behaviour positively and negatively by reference to a set of institutionalized norms. Judgement can be either explicit or implicit and is divided into two broad categories, Social Esteem and Social Sanction, as shown in Table 2.

It is vital, additionally, to distinguish between what can be termed 'inscribed' (or explicit)

Judgement and 'tokens' of Judgement (or implicit Judgement). Inscribed evaluation is explicitly expressed by means of lexical items overtly carrying the Judgement value, thus, skilfully, corruptly, lazily etc. However, Judgement values can be also triggered by 'tokens' of Judgement, in authors' terms. These tokens, may imply Judgement values by apparently neutral, ideational meanings which nevertheless depending upon the reader's social/cultural/ideological reader position, are meant to evoke Judgemental responses.

Appreciation relates to positive and negative assessments of material objects (artefacts, work of art, texts, processes, and so on). In some cases, the choice of particular 
words or phrases overtly states the writer's stance but, generally, the situation is far more complex thus requiring more careful scrutiny. Depending on its more or less immediate 'readability', attitude can be implicitly conveyed, rather than explicitly indicated: Attitude may be either Explicit or Implicit.

Explicit attitude is expressed by overt evaluative/attitudinal words, phrases or sentences, that is to say utterances which straightforwardly communicate a positive or negative sense. As for implicit attitude, on the contrary, it is not easy to locate instances of evaluative/attitudinal expressions. Under implicit Attitude, authors include instances of evaluative/attitudinal expressions, which are not easy to locate: the reader's particular sets of beliefs and expectations will lead him to interpret and consider the writing as un/true, un/acceptable, un/attractive.

Table 2

The full system of Judgement

\begin{tabular}{|c|c|c|}
\hline Social Esteem & positive [admire] & negative [criticise] \\
\hline $\begin{array}{l}\text { Normality } \\
\text { (custom) } \\
\text { 'is the person's } \\
\text { behaviour unusual, special, } \\
\text { customary?' }\end{array}$ & $\begin{array}{l}\text { standard, everyday, average...; } \\
\text { lucky, charmed...; } \\
\text { fashionable, avant garde... }\end{array}$ & $\begin{array}{l}\text { eccentric, odd, maverick...; } \\
\text { unlucky, unfortunate...; } \\
\text { dated, unfashionable... }\end{array}$ \\
\hline $\begin{array}{l}\text { Capacity } \\
\text { 'is the person } \\
\text { competent, } \\
\text { capable?' }\end{array}$ & $\begin{array}{l}\text { skilled, clever, insightful...; } \\
\text { athletic, strong, powerful...; } \\
\text { sane, together... }\end{array}$ & $\begin{array}{l}\text { stupid, slow, simple-minded...; } \\
\text { clumsy, weak, uncoordinated...; } \\
\text { insane, neurotic... }\end{array}$ \\
\hline $\begin{array}{l}\text { tenacity } \\
\text { (resolve) } \\
\text { 'is the person } \\
\text { dependable, well } \\
\text { disposed?' } \\
\end{array}$ & $\begin{array}{l}\text { plucky, brave, heroic...; } \\
\text { reliable, dependable...; } \\
\text { indefatigable, resolute, persevering }\end{array}$ & $\begin{array}{l}\text { cowardly, rash, despondent...; } \\
\text { unreliable, undependable...; } \\
\text { distracted, lazy, unfocussed... }\end{array}$ \\
\hline Social Sanction & positive [praise] & negative [condemn] \\
\hline $\begin{array}{l}\text { Veracity (truth) } \\
\text { 'is the person honest?' }\end{array}$ & $\begin{array}{l}\text { honest, truthful, credible...; } \\
\text { authentic, genuine...; } \\
\text { frank, direct...; }\end{array}$ & $\begin{array}{l}\text { deceitful, dishonest...; } \\
\text { bogus, fake...; } \\
\text { deceptive, obfuscatory... }\end{array}$ \\
\hline $\begin{array}{l}\text { propriety (ethics) } \\
\text { 'is the person ethical, be- } \\
\text { yond reproach?' }\end{array}$ & $\begin{array}{l}\text { good, moral, virtuous...; } \\
\text { law abiding, fair, just...; } \\
\text { caring, sensitive, considerate... }\end{array}$ & $\begin{array}{l}\text { bad, immoral, lascivious...; } \\
\text { corrupt, unjust, unfair...; } \\
\text { cruel, mean, brutal, oppressive... }\end{array}$ \\
\hline
\end{tabular}

Source: P.R.R, WHITE, An introductory tour through appraisal theory. Judgement evaluating human behaviour. http://grammatics. com/appraisal/AppraisalOutline/UnFramed/AppraisalOutline.htm\#P186_38019, (21 December 2011). More details can be obtained on the appraisal website www.grammatics.com/appraisal in the "Introductory Course in Appraisal Analysis".

In 'quality' or 'broadsheet' news media, articles may also be read as 'detached', 'impartial', while at the same time they may advance a particular (axiological) value position. A kind of strategic impersonalisation is mainly achieved by employing a relatively impersonal style, through which attitudinal evaluations and other potentially contentious meanings are largely confined to materials attributed to quoted sources (White 2012: 57, passim).

In particular, reporting verbs and adjuncts can have the double function of indicating the 'stance' both of the (primary) authorial voice vis-à-vis the attributed material, and of the (secondary) quoted source's voice towards such material. 
Key notions concerning the workings of attribution in the news are:

attribution and so-called 'evidentiality', (grounded in Bakhtinian notions of dialogism), leading to strategic impersonalisation;

'invoked' attitude which is further divided into: implicit or 'Provoked' Attitude PrvA (e.g. 'He only visits his extremely frail mother once a year'), and 'Evoked' Attitude - EvkA (e.g. 'Mr Bush was elected president with 500,000 fewer votes than his opponent');

the semantics of reporting (ad)verbs (e.g. say-s/said, tell-s/told, claim-s/ed, reportedly...) and evidentials (it seems/ed, appears/ed, apparently....);

As regards the primary authorial (reporter's) voice, White's frame (2012: 64) outlines different levels as follows:

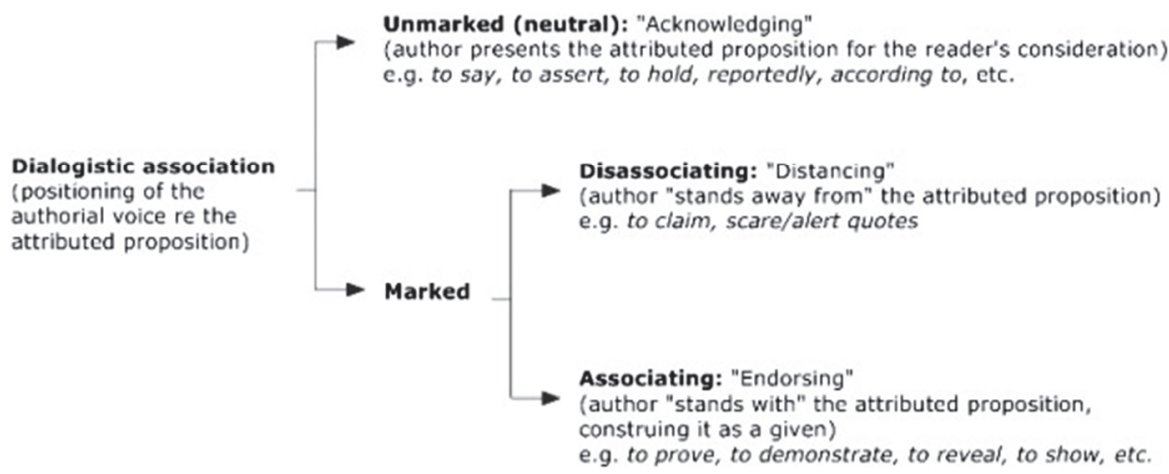

Figure 2. Dialogistic association (White 2012: 64)

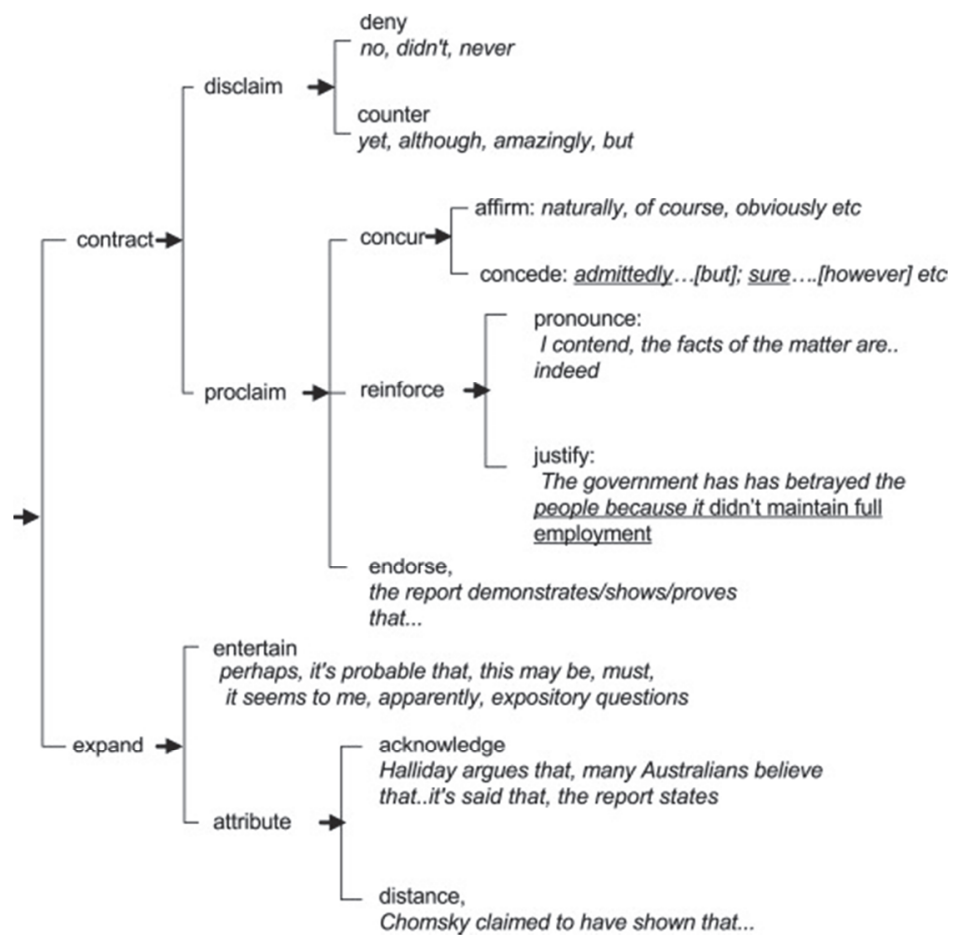

Figure 3. Dialogistic options for the primary voice (White 2012: 65) 
In order to visually represent how the secondary (source's) voice is 'embedded' in the report by the primary voice (i.e. the journalistic voice reporting what the informant/ source voice said about the events), we outlined the following pattern:

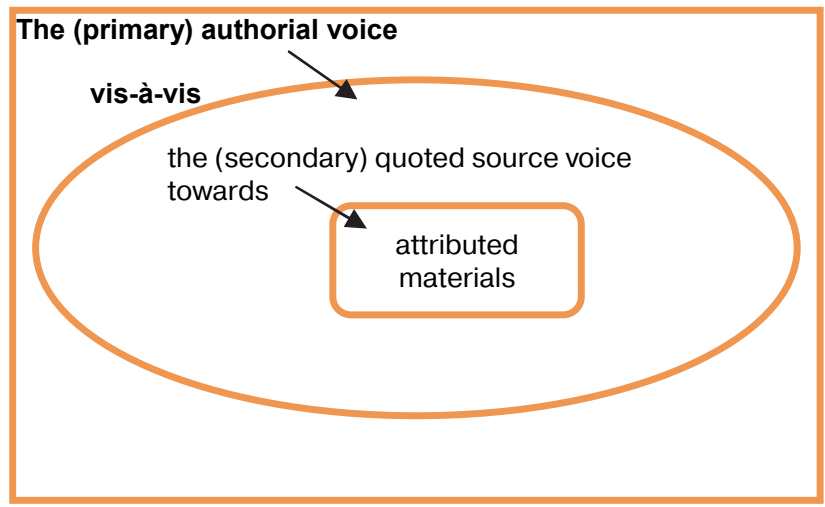

Figure 4. Visualising the 'Chinese boxes' relationship between authorial voice and quoted source voice towards attribuited materials

\section{RACISM IN DISCOURSE-ANALYTICAL TERMS}

Relevantly, in terms of discourse analysis, in our journalistic texts, racial issues are always reported but never (explicitly) supported/endorsed. Nowadays, in official USA communication, an overtly racist attitude would immediately be censured. Nonetheless, racism-tainted ideologies and stereotyped structures are still detectable in some everyday (discursive) practices, mainly in the form of implicitly expressed stereotypes, e.g. "He is Jewish, but he's very nice" (Quasthoff 1978, 1989).

In discourse-analytical terms, one of the most valuable contributions of van Dijk's $(1984,1997)$ model to the investigation of racist discourse is the heuristic assistance it provides in linking the generation of prejudice to larger discursive units than the sentence. According to van Dijk et al (1997), in social memory the collectively shared beliefs of a society are stored and organized as attitudes, and as such are fitted into group schemata that provide the cognitive basis of our information processing about members of outgroups ${ }^{23}$.

${ }^{23}$ Furthermore, Van Dijk's classification of discriminatory acts used to rationalize prejudice against minority groups - the 7 D's of discrimination - is particularly useful in terms of CDA dominance, differentiation, distance, diffusion, diversion, depersonalization or destruction, daily discrimination (van Dijk 1984: 139) Such strategies serve in various ways to legitimize and enact the distinction of "the other", for example, by dominating the minority groups, by excluding them from social activities, and even by destroying and murdering them. van Dijk also analysed "elite racism" (1991, 1993; van Dijk et al 1997), and prejudice stories that were elicited systematically at certain points in interviews with different groups of informants in Amsterdam and in the United States (1984, 1991). These stories are often introduced by procataleptic disclaimers, which allow a positive selfpresentation for the speaker:

a) apparent denials ("I have nothing against Blacks, Turks, Jews, but..."),

b) apparent admissions ("Of course there are also smart Blacks, Turks, Jews, but..."),

c) transfer ("I don't mind so much, but my neighbor, colleagues...") contrast ("We always had to work a lot, but they..."). 
Furthermore, from different visual perspectives, other and even contrasting scenarios can easily be shaped in such and similar cases - even more so in the contemporary web-wired, multimedia, g/local arena, which allows events and related information to resonate in real time beyond socio-geographic constraints. One relevant example is the letter of Trayvon Martin's mother to the Brown family: "If They Refuse to Hear Us, We Will Make Them Feel Us" (Time Magazine, 18 August 2014), which immediately created a virtually visible, empathic bond between the two events.

To this end «newspapers employ textual strategies which foreground the speech act of offering values and beliefs» (Fowler 2013:209) and can favour particular value position, while employing a (seemingly) relatively impersonal style in which evaluations and other potentially contentious meanings are largely confined to material attributed to quoted sources (White 2005, 2012a,b).

From this analytical perspective, our investigation aimed at providing a socio-critical interpretation of how the supposedly unbiased media narratives of ethnic affairs contributed to inflame racial passions, and, by funnelling audience attention toward certain topics and/or by influencing public perceptions of important issues, highlight new social dynamics.

\section{CORPUS}

The present work investigated a selection of print media reports on the killing of Trayvon and related events, in order to highlight how crucial the management of different perspectives can be to effective journalistic communication.

Including and attributing a proposition implies that the writer finds it relevant to the ongoing communicative event. Besides, "By referencing the words of another, the writer, at the very least, indicates that these words are in some way relevant to his/her current communicative purposes. Thus the most basic intertextual evaluation is one of implied relevance" (White 2015). According to relevance criteria ${ }^{24}$, we extrapolated excerpts from the two sub-corpora (The New York Times; Orlando Sentinel) under examination and investigated the linguistic choices made by these two newspapers. From the killing of Trayvon Martin (26 February 2012) to the acquittal of George Zimmerman (13 July, 2013), thousands of articles have been published in the USA print

24 The notion of relevance, amplified from the usual acceptation of the word, traditionally pertained psychological and cognitive studies (among others, Higgins and Bargh 1987; Humphreys and Garry 2000; Fecteau and Munoz 2006), and has recently been utilized in communication studies and linguistics as well. Moving from Grice's maxims of conversation, in the 1980s and 1990s Sperber and Wilson developed the Relevance theory $(1986,1997)$, with attention to the context and the cognitive environment where the speech acts take place. Hence, relevant become: a) data or findings taken to bear on some phase or aspect of linguistic analysis; b) whatever bears on the meaning of an utterance; c) an utterance said on a specific occasion. Thus, speakers/writers are expected by a maxim of relation to make their contribution to an interchange relevant rather than irrelevant (see also Jaworski and Coupland 2006). From this and contiguous perspectives Content value, Cognitive value, Socio-emotional value, Information source value, become relevant (Soojung et al. 2007). For our analysis the socio-emotional value was particularly prominent, especially when journalistic voices report/display opinions and emotions, which we analysed by utilizing the AF Affect and Judgement categories for the first set of data. Then, for the second set of data, the more relevant aspect was the interplay of different voices investigated though the category of Attribution. 
media. For our investigation, we selected 20 articles from The New York Times (NYT) and 20 from Orlando Sentinel (OS), according to relevance criteria, i.e., more specifically, the recognizable presence of a reported source. The total running words are 25.884 for NYT and 21711 for OS.

The New York Times was chosen because it is the largest daily local metropolitan newspaper in the United States and the third in national circulation (after USA Today and The Wall Street Journal) and is regarded as an authoritative national newspaper of public record. In order to compare print media communication at the national and local level, Orlando Sentinel was chosen, as it is the primary newspaper of Orlando (Fla), and of the Central Florida region. It has historically tilted conservative; it has only endorsed a Democrat for president three times since 1964 (Lyndon Johnson in 1964, John Kerry in 2004 and Barack Obama in 2008).

\section{AF FRAMING OF THE DATA ATTRIBUTION FRAMING OF THE DATA}

The different modes of Attribution highlighted in the Tables below are presented as follows:

\section{LEGEND}

- primary voice — pv (i.e., the reporter's voice): e.g. "Mr. Obama said"pv"

- secondary voice - sv (i.e., the source's voice): e.g. "All of us have to do some soul searching to figure out how does something like this happen. ${ }^{\text {sv" }}$

- attributed materials - AM

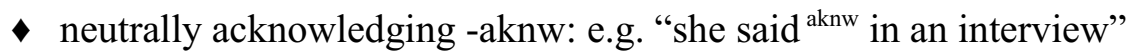

- distancing - DST: "He cautioned ${ }^{\mathrm{DST}}$ that"

- endorsing - ENDS: e.g. prove, demonstrate

- 'evoked' attitude — EkdA: e.g. "unarmed black high school student ${ }^{\text {EkdA", }}$

- 'provoked' attitude - PkdA: e.g. "who had been carrying only an iced tea and a bag of Skittles. ${ }^{\text {PkdA"') }}$

- reporting (ad)verbs in italics: e.g. reported/ly)

- evidentials in bold: e.g. seems/ed, appears/ed... apparently)

However, since it could be confusing to highlight all (embedded) modes in the same Tables, only the salient characteristics of each excerpt will be pointed out, though with some predictable overlapping. The Tables below therefore clearly illustrate how this dialogistic interplay is deployed in print media texts.

\section{EXCERPTS FROM THE NEW YORK TIMES}

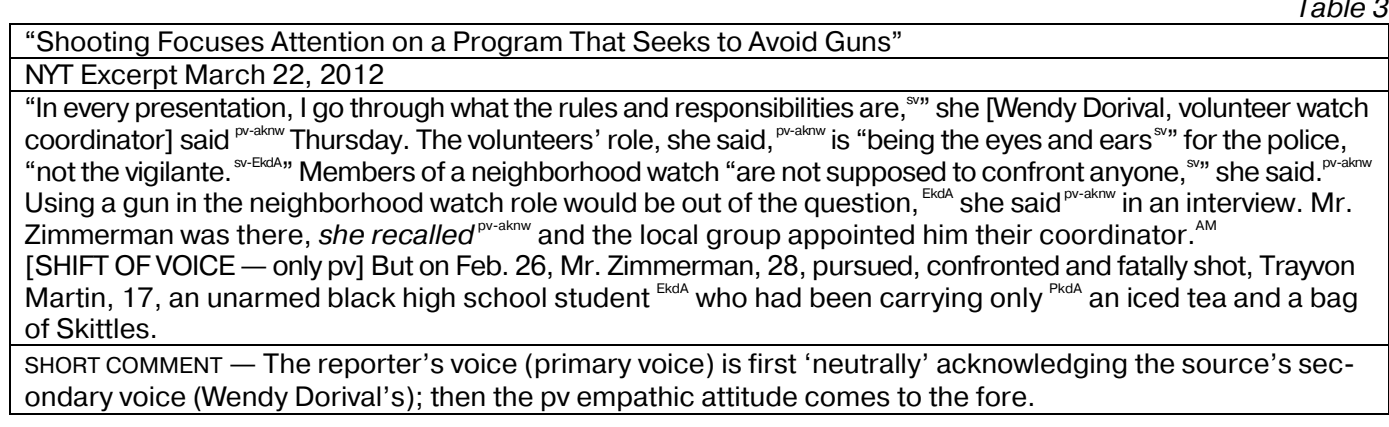


Table 4

"Obama Speaks Out on Trayvon Martin Killing"

NYT Excerpt - March 23, 2012

The president often appears ${ }^{\mathrm{pv}}$ perturbed when he is asked off-topic questions at ceremonial events, but on Friday, he seemed ${ }^{\mathrm{pv}}$ eager to address the case, which has quickly developed into a cause ch̆lnbre around the country. He cautioned ${ }^{\text {Sv-DST }}$ that his comments would be limited because the Justice Department was investigating. But he talked at length ${ }^{\text {pvaknw }}$ about his personal feelings about the case. "I think every parent in America should be able to understand why it is absolutely imperative that we investigate every aspect of this, ${ }^{\text {sv-PkdA" }}$ Mr. Obama said. pv-aknw "All of us have to do some soul searching to figure out how does something like this happen. sv-PkdA" $^{-}$

SHORT COMMENT - The (reporter's) primary voice's general attitude is endorsing; the secondary voice's belongs to a 'specified' source (i.e., a named individual, Mr. Obama ${ }^{25}$ ) and displays patent 'affectual' tones.

Table 5

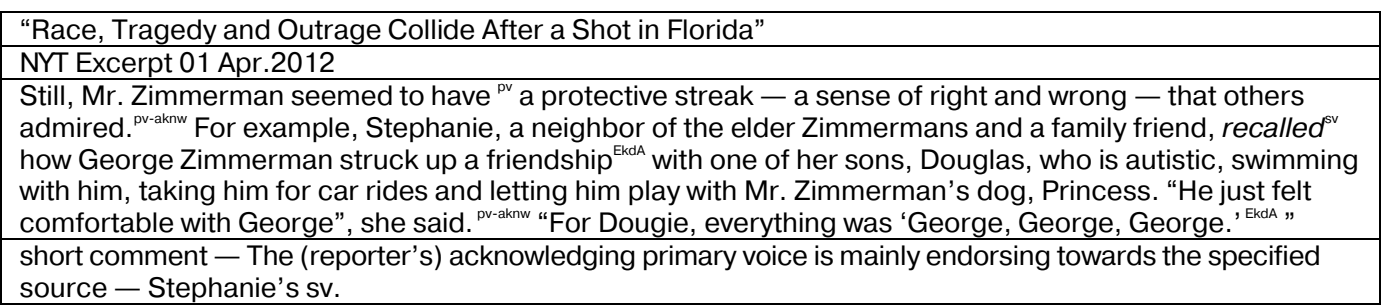

Table 6

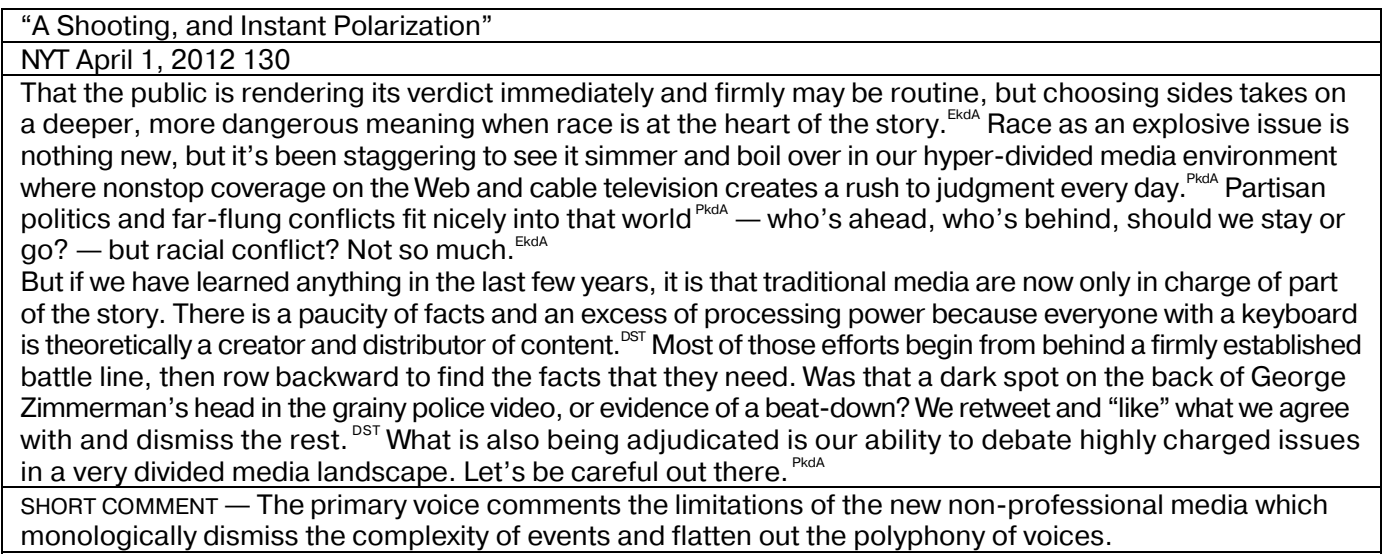

\section{EXCERPTS FROM ORLANDO SENTINEL}

Table 7

\begin{tabular}{|c|}
\hline O.S. Excerpt - March 14, 2012 \\
\hline 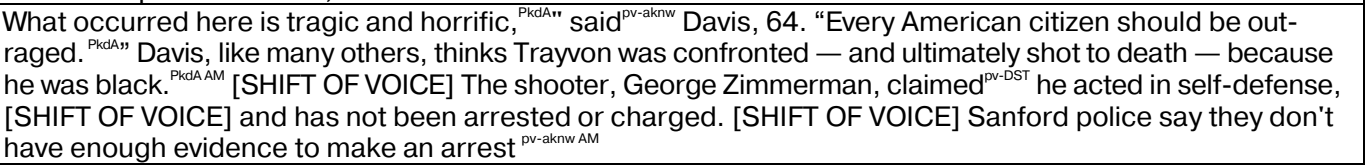 \\
\hline $\begin{array}{l}\text { SHORT COMMENT - Here the (reporter's) primary voice displays different attitudes to different secondary } \\
\text { voices mainly to the effect of dis-endorsing Zimmerman. }\end{array}$ \\
\hline
\end{tabular}

${ }_{25}$ The other option being 'genericized', i.e., when the material is presented as sourced from a generalised class such as 'scientists' or 'economists'(White 2012 b). 
"Should 'stand your ground' change?"

O.S. Excerpt - February 25, 2013

Zimmerman took a leadership role in organizing his community's Neighborhood Watch, amid a string of burglaries, ${ }^{\text {PkdA }}$ some reportedly perpetrated by black teens. ${ }^{\text {PkdA }}$ He often reported people he found suspicious to police. The last was Trayvon. Is Zimmerman racist? Reports released so far from an FBI civil rights investigation have turned up little to say he is. ${ }^{\text {EdAAM }}$ However, a former coworker accused Zimmerman of racial insults, ${ }^{\mathrm{AM}}$ and a relative, who also says ${ }^{\mathrm{sv}}$ Zimmerman molested her when they were both children, told $^{\text {sv }}$ investigators Zimmerman and his kin don't like black people. ${ }^{\text {AM }}$

SHORT COMMENT - The (reporter's) primary voice neutrally refers contrasting opinions. However, the pv's non-committal attitude towards other allegations against Zimmerman ends up by subtly endorsing him.

Table 9

\begin{tabular}{|l|}
\hline "Tensions still simmer in Trayvon Martin shooting case" \\
\hline O.S. Excerpt - March 17, 2012 \\
\hline A series of 911 calls from the last moments of Trayvon's life ${ }^{\text {PkdA }}$ were supposed to shed light on why police have \\
not arrested the shooter, ${ }^{\text {PkA }}$ crime-watch volunteer George Zimmerman. Instead, they have fueled even more \\
rage $^{\text {PkdA }}-$ not just in Central Florida, but across the country. Trayvon's family and supporters vowthey won't \\
give up until Zimmerman is charged with the 17 -year-old's slaying late last month. ${ }^{\text {AM ENDS }}$ At the heart of this \\
maelstrom - in which the thorny issues of race and justice have surfaced as themes ${ }^{\text {Pkd }}-$ is a boy who \\
dreamed of becoming a pilot and liked to work with his hands. ${ }^{\text {PdA }}$ \\
\hline short comment - The (reporter's) primary voice empathically refers the event strongly endorsing the Martin \\
family and their supporters' involvement and stance, also by setting the untimely death of Trayvon against \\
the background of his expectations for the future.
\end{tabular}

Table 10

"Police: Zimmerman says Trayvon decked him with one blow then began hammering his head"

March 26, 2012

[PV] With a single punch, Trayvon Martin decked the Neighborhood Watch volunteer who eventually shot and killed the unarmed 17-year-old, then Trayvon climbed on top of George Zimmerman and slammed his head into the sidewalk, leaving him bloody and battered, law-enforcement authorities told the Orlando Sentinel. ${ }^{\mathrm{AM}}$ That is the account Zimmerman gave police, and much of it has been corroborated by witnesses, ${ }^{A M}$ authorities say. ${ }^{\text {aknw }}$ There have been no reports that a witness saw the initial punch Zimmerman told police about. ${ }^{\text {DST }}$ Zimmerman has not spoken publicly about what happened Feb. 26. But that night, and in later meetings, he described and re-enacted for police what he says took place. ${ }^{\text {DST }}[\ldots]$

[SV] Civil-rights leaders and more than a million other people have demanded Zimmerman's arrest, calling Trayvon a victim of racial profiling and suggesting Zimmerman is a vigilante. Trayvon was an unarmed black teenager who had committed no crime, ${ }^{\mathrm{EkdA}}$ they say, ${ }^{\mathrm{sv}}$ who was gunned down while walking back from a 7-Eleven store with nothing more sinister than a package of Skittles and can of Arizona iced tea. ${ }^{\text {PkdA }}$ SHORT COMMENT - In the first excerpt from this article, the reporter's voice (pv) refers Zimmermann's version in an apparently neutral mode, though a distancing attitude towards the attributed materials is discernable. In the second, the source's secondary voice (i.e., civil-rights leaders, etc.) emerges in the lexical choices conveying strongly empathic attitudes.

Table 11

"Facts vs. Rumours"
O.S. Excerpt - 2 April 2012
Trayvon took his last breath in a bed of damp grass just feet from the safety of a relative's home a few minutes
before the NBA All-Star Game was set to tip off in Orlando.
short comment - Again, the (reporter's) primary voice empathically refers the event by dramatically depicting
the circumstances.




\section{DISCUSSION}

Overall, we can say that the dynamics of strategic impersonalization are more subtly operated in The New York Times, though both newspapers (The New York Times and Orlando Sentinel) - as professional print media — skilfully avoided taking an explicit position or displaying emotional attitudes on burning issues, mainly by attributing opinions and attitudes to quoted sources. The entailed issues concern the readers' fruition/ position and inferences. To what extent do print media readers typically read news texts as 'factual' and 'neutral', so that their value positions are naturalised/accepted tout court? Referring to the relevance criterion of inference (Sperber and Wilson 1986, 1995, 1997), we can assume that the inferential comprehension of the journalistic authors' stances relies on the deductive processing of the information, which is "spontaneous, automatic, and unconscious, and it gives rise to certain contextual effects in the cognitive environment of the audience" (Jaworski and Coupland 2006: 15). Simply put, the readership should be able, predictably, to infer the journalistic authors' value positions and stances.

However, as our analysis highlighted, the communicative arrangements by which the journalistic authors dialogistically engage with the diversity of voices and viewpoints can be sophisticated, and the primary and secondary voices' interplay in the print newsreporting texts in conveying underlying axiological/attitudinal orientations can become complex. Hence, it can be difficult for readers to be aware of the underlying axiological interests at stake and to unveil such impersonalisation strategies. To gauge and measure the extent of the print media readers' awareness could be an interesting topic for further investigation in the domain of cognitive research.

\section{CONCLUDING REMARKS}

Clashing sociocultural scenarios turned the killing of Trayvon and its aftermath into an impressive media battle by fuelling a national confrontation about the thorny issues of race, profiling, self-defense laws and gun control and their interplay. In this arena we investigated examples of print media (meta-)discourse/s, aiming to highlight the multi-layered interplay of primary and secondary professional journalistic voices, following the dynamics of strategic impersonalization. Indeed, nowadays, professional journalistic writers are only partially in charge of news and opinions communication, and concerns are voiced on how and to what extent "the excess of processing power allows everyone with a keyboard [...to become] theoretically a creator and distributor of content. [...] We retweet and "like" what we agree with and dismiss the rest" (Carr $2012)^{26}$, regardless of considerations of reliability and quality of the news. We are increasingly experiencing how the social media (FB, Twitter etc), fora, blogs and platforms for change (the most famous one being "Change.org") enable individuals and groups to mobilize support by forming posses, and win change both at local and at global level. Only thanks to the media attention and coverage - i.e. to the court of public opinion - could the case be presented to a court of law, where Zimmerman was charged with second degree murder (though later acquitted). As the Martins' lawyer,

${ }^{26}$ D. Carr. A Shooting, and Instant Polarization. The New York Times (April 1, 2012). 
Benjamin Crump, said, "Thank God for the media, because I'm not sure we ever would have gotten the truth out" (Boedeker and Comas 2012) ${ }^{27}$. The lawyers for the Martin family became frequent TV guests on morning programs, cable news and local newscasts. Martin/Zimmerman case shows how contemporary interactive news culture can re-shape and even reverse the course of events: without such a volume of media attention, the State of Florida vs Zimmermann trial would never have taken place.

(C) Flavia Cavaliere, 2018

\section{REFERENCES}

Abbamonte, L. (2012). Integrated Methodology for Emotion Talk in Socio-legal Exchanges. Politeness, Accommodation and Appraisal Insights. Napoli: Edizioni Scientifiche Italiane.

Adjei, P. B., \& Gill, J. K. (2013). What has Barack Obama's election victory got to do with race? A closer look at post-racial rhetoric and its implication for antiracism education. Race Ethnicity and Education, 16(1), 134-153.

Babacan, H., Gopalkrishnan, N., \& Babacan, A. (2009). Situating racism. The local, national and the global. Newcastle: Cambridge Scholars.

Bhandaru, D. (2013). Is White Normativity Racist? Michel Foucault and Post-Civil Rights Racism. Polity, 45(2), 223-244.

Bhatia, V., Candlin, C., Engberg, J. (2008). Legal Discourse across Cultures and Systems. Hong Kong: Hong Kong University Press.

Burns, A. R., Matarazzo O, Abbamonte L. (2014). Corpus Linguistics and the Appraisal Framework for Retrieving Emotion and Stance - The Case of Samsung's and Apple's Facebook Pages. In Bassis S., Esposito A., Morabito F. C. (eds) Recent Advances of Neural Networks Models and Applications. vol. 26, pp. 283 -294, Springer, ISBN: 978-3-319-04128-5, doi: 10.1007/9783-319-04129-2.

Cavaliere, F. (2012). The Shaping of the News. How Information can be moulded by the Press. Roma: Edizioni Nuova Cultura.

Clore, G. L., \& Huntsinger, J. R. (2007). How emotions inform judgment and regulate thought. Trends in Cognitive Sciences, 9, 393-399.

Clore, G.L. \& Schnall, S. (2008). Affective Coherence: Affect as Embodied Evidence in Attitude, Advertising, and Art. In G. R. Semin, E. Smith (eds) Embodied Grounding: Social, Cognitive, Affective, and Neuroscientific Approaches, New York: Cambridge University Press, pp. 211236.

Colombo, M. (2004). Theoretical Perspectives in Media-Communication Research: From Linear to Discursive Models. Forum: Qualitative Social Research, [S.1.], 5 (2), May.

Dolan, R. J. (2000). Emotion, cognition, and behavior. SCIENCE 298 (5596) 1191-1194.

Goodwin, C. (1994). Professional Vision. American Anthropologist. 96 (3): 606-633.

Higgins, E. T., \& Bargh, J. A. (1987). Social cognition and social perception. Annual Review of Psychology, 38, 369-425.

Humphreys, M. \& Garry, J. (2000). Thinking about salience. Early drafts from Columbia, pp. 1-55.

Izard, C. E. (1997). Human Emotions. New York: Plenum Press.

Jaworski, A. \& Coupland, N. (eds). (2006). The Discourse Reader. London and New York: Routledge.

${ }^{27}$ H. Boedeker and M. E. Comas. Dueling scenarios helped shape Trayvon story in epic media battle. Orlando Sentinel (September 29, 2012). 
Martin, J.R. \& White, P.R.R. (2005). The Language of Evaluation. Palgrave Macmillan, London \& New York.

O' Meara, G. (2012). Stand Your Ground Laws Are Unnecessary. March 21. The New York Times.

Parkinson, B., Fischer, A., \& Manstead, A. S. R. (2005). Emotion in social relations: Cultural, group, and interpersonal processes. New York: Psychology Press.

Prinz J. (2006). The Emotional Basis of Moral Judgements. Philosophical Explorations, 9, (1).

Prinz, J. J. (2004). Embodied emotions. In R. C. Solomon (ed.), Thinking about feeling: Contemporary philosophers on emotions. New York: Oxford University Press, pp. 44-58.

Quasthoff, U. (1978). The uses of stereotype in everyday argument. J. Pragmat. 2(1), 1- 48.

Quasthoff, U. (1989). Social prejudice as a re-source of power: towards the functional ambivalence of stereotypes. In R. Wodak (ed) Language, Power, and Ideology, pp. 137-63. Amsterdam: Benjamins.

Roseman, I. J., \& Smith, C. A. (2001). Appraisal theory: Overview, assumptions, varieties, controversies. In K. R. Scherer, A. Schorr, \& T. Johnstone (eds.), Appraisal processes in emotion: Theory, methods, research (pp. 3-19). New York: Oxford University Press.

Sperber, D. \& Wilson, D.1986 [1995]. Relevance: Communication \& Cognition, Oxford: Blackwell. — 1997. 'Remarks on relevance theory and the social sciences.'Multilingua 16: 145-152.

Van Dijk T.A. (1984). Prejudice in Discourse. Amsterdam: Benjamins.

- 1985. Discourse and Communication: New Approaches to the Analysis of Mass Media Discourse and Communication. Walter de Gruyter.

- 1991. Racism and the Press. Critical Studies in Racism and Migration. London: Routledge.

Van Dijk T.A, Ting-Toomey S, Smitherman G, Troutman D. (1997). Discourse, ethnicity, culture and racism. In Van Dijk T.A (ed). Discourse as Social Interaction. London: Sage.

Voloshinov, V.N. (1995). Marixism and the Philosophy of Language, Bakhtinian Thought an Introductory Reader. S. Dentith, L. Matejka \& I.R. Titunik, (trans), London: Routledge.

Wetherell, M. and Potter, J. (1992). Mapping the Language of Racism: Discourse and the Legitimation of Exploitation. London and New York: Harvester Wheatsheaf and Columbia University Press.

White, P.R.R. (1998). 'Telling Media Tales: the News Story As Rhetoric'. Unpublished Ph.D Dissertation, University of Sydney, Sydney. Retrieved from: http://www.grammatics.com/appraisal/ whiteprr/whiteprr_phd.html.

White, P.R.R. (2012). Exploring the axiological workings of 'reporter voice' news stories Attribution and attitudinal positioning. Discourse, Context and Media, 1(2-3), 57-67.

Wodak, R. and M. Reisigl. (1999). Discourse and Racism: European Perspectives. Annual Review of Anthropology, 28, 175-199.

The 2013 Florida Statutes: CHAPTER 776 JUSTIFIABLE USE OF FORCE

http://www.leg.state.fl.us/statutes/index.cfm?App_mode=Display_Statute\&URL=07000799/0776/0776.html.

Article history:

Received: 08 December 2017

Revised: 12 January 2018

Accepted: 24 January 2018

For citation:

Cavaliere, Flavia (2018). Discursive Mechanisms of News Media - Investigating Attribution and Attitudinal Positioning. Russian Journal of Linguistics, 22 (1), 338-356. doi: 10.22363/2312-9182-2018-22-2-338-356. 


\title{
Bionote:
}

FLAVIA CAVALIERE is Aggregate Professor of English Language and Translation at the Department of Human Studies of the University of Naples Federico II. Research interests: Translation Studies, AudioVisual Translation, Cross-cultural Communication, Language and Media, Multilingualism, Critical Linguistics and (multimodal) Discourse Analysis, Appraisal Theory, English for Special (Academic) Purposes and the translation of scientific texts. Contact information: e-mail: fcavalie@unina.it

\section{DOI: 10.22363/2312-9182-2018-22-2-338-356}

\section{ДИСКУРСИВНЫЕ МЕХАНИЗМЫ СМИ: ТЕХНОЛОГИИ АТРИБУЦИИ И ПОЗИЦИОНИРОВАНИЯ}

\author{
ФЛАВИЯ КАВАЛЬЕРИ \\ Неаполитанский университет имени Фридриха II \\ 1 Via Porta di Massa, Naples, 80133, Italy
}

В 2012 году американский патрульный-волонтер Джордж Циммерман застрелил 17-летнего чернокожего подростка Трейвона Мартина. Это убийство продолжило цепочку трагических событий, связанных с нападениями на невооруженных афроамериканских граждан, вызвало массовую волну протестов, разговоров о проявлении расизма и чрезмерной свободе владельцев оружия в США. Первоначально власти не выдвинули обвинений против Джорджа Циммермана, ссылаясь на закон о применении оружия при самообороне, действующий на территории штата Флорида. Более двух миллионов американцев подписали онлайн-петицию с требованием справедливого правосудия и ареста Циммермана. Джордж Циммерман предстал перед судом, однако в 2013 году ему был вынесен оправдательный приговор. На вышеупомянутый вердикт резко отреагировали представители различных кругов американской общественности. В социальных сетях начало свое существование международное движение активистов, выступающих против насилия в отношении чернокожего населения с использованием хештега \#BlackLivesMatter. «Дело Циммермана» продолжает широко освещаться в СМИ. Журналисты «используют речевые стратегии, выходящие за рамки речевых актов, отображающих ценности и убеждения» (Fowler, 2013: 209). В статье, в соответствии с теорией оценки Мартина и Уайта (2008) были исследованы качественные образцы американских печатных изданий (The New York Times и Orlando Sentinel), тем или иным образом рассказывающих историю Трейвона Мартина. Особое внимание при анализе текстов статей уделяется атрибуции и эвиденциальности (сочетание цитируемой и косвенной речи при описании событий, версий, мнений). Цель статьи: представить социально-критическую интерпретацию того, как предположительно непредвзятые сюжеты этнических споров способствуют разжиганию расовой неприязни и влияют на общественное восприятие данной проблемы.

Ключевые слова: освещение в СМИ, расовые проблемы, атрибуияя, позиционирование, общественное восприятие

\section{История статьи:}

Дата поступления в редакцию: 8 декабря 2017

Дата принятия к печати: 24 января 2018

\section{Для цитирования:}

Cavaliere, Flavia (2018). Discursive Mechanisms of News Media - Investigating Attribution and Attitudinal Positioning. Russian Journal of Linguistics, 22 (1), 338-356. doi: 10.22363/2312-9182-2018-22-2-338-356.

\section{Сведения об авторе:}

ФЛАВИЯ КАВАЛЬЕРИ - доктор филологических наук, доцент кафедры английского языка и переводоведения, Неаполитанский университет имени Фридриха II. Сфера научных интересов: перевод и переводоведение, аудиовизуальный перевод, межкультурная коммуникация, язык СМИ, мультилингвизм, критический дискурс-анализ. Контактная информация: e-mail: fcavalie@unina.it 